\title{
VERTICAL PRICE TRANSMISSION IN SOYBEAN, SOYBEAN OIL, AND SOYBEAN MEAL MARKETS
}

\section{Josua Desmonda Simanjuntak ${ }^{* * *) 1}$, Stephan von Cramon-Taubadel ${ }^{*}$, Nunung Kusnadi**), and Suharno**)}

\author{
*) Department of Agricultural Economics and Rural Development, Georg-August-Universität Göttingen \\ Platz der Göttingen Sieben 5, 37073, Göttingen, Germany \\ **) Department of Agribusiness, Faculty of Economics and Management, IPB University \\ Jl. Agatis, IPB Dramaga Campus, Bogor 16680, Indonesia
}

\begin{abstract}
Soybean is becoming a prominent agricultural industry due to its versatility of use as inputs for different industrial sectors. Soybean products have a high value and are profitable since its huge supply and wide demand. The soybean economic value does belong to the commercial use of its joint products, soybean meal, and soybean oil. Joint product theory assumes the price of soybeans can be represented as a weighted average of returns from soybean meal and soybean oil less than the processing margin. This indicates there are price relationships between soybean as a raw product towards its meal and oil through crush processing. Therefore, the objective of this research is to investigate the price transmission between these three products and analyzed factors that influencing them. Monthly time series data in respect of international prices were obtained. Augmented Dickey-Fuller (ADF) test and the Johansen cointegration technique were utilized to test the stationarity and the longrun relationship between three variables respectively. The result indicates the existence of one cointegrating long-run equilibrium relationship between these variables. The Vector Error Correction Model (VECM) estimates revealed that soybean price is the only one that reacts to correct equilibrium since oil and meal have huge markets.
\end{abstract}

Keywords: soybean, soybean meal, soybean oil, joint product, VECM

Abstrak: Kedelai menjadi industri pertanian terkemuka karena kegunaannya yang beragam sebagai input untuk berbagai sektor industri. Nilai ekonomi kedelai bergantung pada komersialisasi penggunaan produk gabungannya, bungkil kedelai, dan minyak kedelai. Teori produk gabungan mengasumsikan bahwa harga kedelai dapat direpresentasikan sebagai ratarata tertimbang pendapatan dari penjualan bungkil kedelai dan minyak kedelai dikurangi margin pengolahannya. Hal ini mengindikasikan akan adanya hubungan transmisi harga dari kedelai sebagai produk mentah terhadap bungkil dan minyaknya melalui proses penggilingan ini. Oleh karena itu, tujuan dari penelitian ini adalah untuk menyelidiki transmisi harga antara ketiga produk ini dan menganalisis faktor-faktor yang mempengaruhinya. Penelitian ini menggunakan data harga internasional bulanan untuk ketiga produk. Tes Augmented DickeyFuller (ADF) dan teknik kointegrasi Johansen digunakan untuk menguji stasioneritas dan hubungan jangka panjang. Hasilnya menunjukkan adanya satu hubungan kointegrasi atau ekuilibrium jangka panjang kointegrasi diantara ketiga variabel. Kemudian, hasil estimasi Vector Error Correction Model (VECM) menunjukkan bahwa harga kedelai adalah satusatunya yang bereaksi untuk memperbaiki keseimbangan. Hal ini disebabkan minyak kedelai dan bungkil kedelai memiliki pasar yang besar secara global.

Kata kunci: kedelai, bungkil kedelai, minyak kedelai, produk gabungan, VECM

\footnotetext{
${ }^{1}$ Corresponding author:

Email: j.simanjuntak@stud.uni-goettingen.de
} 


\section{INTRODUCTION}

Soybean becoming prominent agricultural industries with an increase of 355 million metric tons in the global supply. Demand for soybean continues to grow in the future as demand for various products. According to Freitas et al. (2001), soybean is one of the most traded agricultural products worldwide, possibly because of the varied types of consumption, ranging from the food (human to animal), the medical, and industries. Besides, soybean has an essential place in the world's oilseed cultivation scenario due to its high productivity and profitability (Margarido et al. 2007).

In terms of productivity, soybean contributes around $60 \%$ to the global oilseed supply. Soybean supply prominently surpasses other oilseed supplies like rapeseed and sunflower seed. The average soybean oilseed supply in the last five years was five times larger than the second-highest oilseed supply, which was 344 million metric tons compared to 71 million metric tons of rapeseed (USDA, 2019).

Moreover, soybean has high profitability due to its versatility uses as inputs for different industrial sectors. Soybean processing industry generally produces meal and oil, called joint products, through mechanical or solvent extraction. Mechanical extraction involves crushing soybeans to remove oil and heat the meal to enhance the digestibility for livestock. Meanwhile, solvent extraction uses chemicals to separate the oil and meal (Ishler (2006) cited in Pritchett et al. 2016).

Soybean, through its joint products, also gives a high contribution to world primary oilseed consumption. Soybean continues to remain by far as the most crucial protein meal source in the world, contributing $70 \%$ of global protein meal consumption with 238 million tons in 2019. At the same time, soybean was the most widely consumed vegetable oil in the world next to oil palm, with a total consumption of over 57 million tons.

These data reveal the importance of soybean and its joint products for the global food and feed industry. Due to its vast supply and broad demand, soybean products perhaps have high value and profitable. This possibly generates considerable value addition occurs in downstream production level, crush processing industry, domestic market, and even encourage countries to export their soybean products.
Specifically, the soybean economic viability does belong to the commercial use of its joint products. Soybean meal and soybean oil value respectively account for about four-fifth and one-fifth of the soybean economic value. Hence, there is a possibility of a correlation between soybean as a raw product and its joint product, which will be analyzed further in this research.

Research to date on soybean price transmission has focused on spatial and vertical correlation within market price. Respect to factors that affect horizontal price transmission in the soybean market, Margarido et al. (2007) investigated the soybean spatial price transmission between Brazil and three relevant international markets, such as Rotterdam Port, Argentina, and the United States. Furthermore, Soon and Whistance (2019) examined whether there was seasonality effect in the price transmission between the U.S. and Brazil soybean prices, soybean meal, and soybean oil, using the seasonal regime dependent VECM. However, the importance of this research does not capture price transmission of soybean towards its joint product, oil, and meal. To achieve this, the soybean market cointegration and price transmission towards its joint product price are analyzed in this research. Using monthly time-series data, this research examines price transmission between soybean, soybean meal, and soybean oil from January 1996 to May 2019 with Vector Error Correction Model (VECM).

Based on the background outlined above, some questions are asked relating to price transmission of soybean and its joint products. The aims of this research are assessing the market integration and price transmission between soybean and its joint products and analyze which factors that influencing price transmission of soybean and its joint products.

\section{METHODS}

This study used secondary time series data for soybean, soybean meal, and soybean oil. The data is obtained from GIEWS FPMA Tool, provided by the Food and Agriculture Organization (FAO) of the United Nations. The analysis used 281 monthly observations that provided by FAO from January 1996 to May 2019. Since working with time- series data, the whole data that provided by FAO are used to get recent results and robust interpretation. Besides, Rotterdam soybean 
price, Hamburg soybean meal price and Dutch soybean oil price are used since all these three prices represent international prices. The unit of the prices is in USDollar/tonne. To investigate the price transmission in soybean joint product markets, several steps were performed. This research examined the data by using the unit root test, the cointegration test, and the estimation of the VECM. Since the number of monthly data is high enough, an econometric approach was provided in this analysis. To process the data, GRETL and STATA software was performed. The hypothesis is there is at least one long-term relationship (cointegration) between all three prices simultaneously. Thus, VECM is constructed since the variables are cointegrated.

\section{Unit Root Test}

To be specific, suppose the third equation is used. The $\mathrm{ADF}$ test here consists of estimating the following regression:

$$
\Delta y_{t}=\beta_{1}+\beta_{2} t+\gamma y_{t-1}+\sum_{i=1}^{m} \alpha_{i} \Delta y_{t-i}+v_{t}
$$

where $v_{-} t$ is a pure white noise error term and where $\Delta \mathrm{y}_{\mathrm{t}-1}=\left(\mathrm{y}_{\mathrm{t}-1}-\mathrm{y}_{\mathrm{t}-2}\right), \quad \Delta \mathrm{y}_{\mathrm{t}-2}=\left(\mathrm{y}_{\mathrm{t}-2}-\mathrm{y}_{\mathrm{t}-3}\right), \ldots$ As many lagged first difference terms needed was added to ensure that the residuals are not autocorrelated. Including lags of the dependent variable can be used to eliminate autocorrelation in the errors. The number of lagged terms can be determined by examining the autocorrelation function (ACF) of the residuals $\mathrm{v}_{\mathrm{t}}$, or the significance of the estimated lag coefficients $\alpha_{i}$ (Hill et al. 2011).

To obtain robust data, the Phillip-Perron (PP) test performed in this research. In the research on financial time series, Phillipps and Perron (1988) carried out several root trials (Hamilton, 1994). The root checks for the Phillips-Perron unit vary from those of ADF, primarily because of their treatment of sequential associations and errors. When parametric self-regression is used by ADF tests to estimate the ARMA structure of the test-regression errors, PP testing does not consider all serial correlations during test-regression (Hamilton, 1994). $\Delta \mathrm{y}_{\mathrm{t}}=\beta^{\prime} \mathrm{D}_{\mathrm{t}}+\pi \mathrm{y}_{\mathrm{t}}-1+\mathrm{u}_{\mathrm{t}}$

where $u_{t}$ is $I(0)$. One advantage of the PP tests over the ADF tests is that the PP tests are robust to general forms of heteroskedasticity in the error term $u_{t}$. Another advantage is that the user does not have to specify a lag length for the test regression (Hamilton, 1994).

\section{Determination of Optimum Lag}

The purpose of this process is to prevent the possibility of residual autocorrelation in the time series data on the prices of soybean, soybean meal, and soybean oil. To capture the effect of each variable to others in the model, the optimal lag duration of the variable is needed. There are some criteria to choose the appropriate lag length, e.g. Akaike Information Criterion (AIC), Schwarz Bayesian Criterion (BIC), dan Hannan-Quinn Information Criterion (HQC) (Arnold et al. 2008).

\section{Cointegration Test}

According to Engle and Granger (1987), two I(1) series are said to be cointegrated if there exists some linear combination of the two, which produces a stationary trend $[\mathrm{I}(0)]$. Any non-stationary series that are cointegrated may diverge in the short run, but they must be linked together in the long run.

There are two test statistics for cointegration under the Johansen approach, which are formulated as:

$$
\begin{gathered}
\lambda_{\text {trace }}(r)=-T \sum_{i=r+1}^{n} \ln \left(1-\hat{\lambda}_{i}\right) \\
\lambda_{\text {max }}(r, r+1)=-T \ln \left(1-\hat{\lambda}_{r+1}\right)
\end{gathered}
$$

where $\hat{\lambda}_{t}$ (the estimated values of the characteristic roots (also called eigenvalues) obtained from the estimated $\pi$ matrix); $\mathrm{T}$ (the number of usable observations

When the appropriate values of $\mathrm{r}$ are clear, these statistics are referred to as $\lambda_{\text {trace }}$ and $\lambda_{\text {max }}$ ). The $\lambda_{\text {trace }}$ test the null hypothesis that the number of distinct cointegration vector is less than or equal to $r$ against a general alternative, meanwhile $\lambda_{\max }$ tests the null hypothesis that the number of cointegrating vectors is $r$ against the alternative of $r+1$ cointegrating vectors (Enders, 2015).

\section{Vector Error Correction Model}

The first step in the analysis should be to determine whether the levels of the data are stationary. If not, take the first differences in your data and try again. Usually, if the levels (or log-levels) of the time series are not stationary, the first differences will be (Hills et al. 2011). 
When $y$ and $x$ are $I(1)$ and co-integrated, the framework may be modified to allow the cointegration of the variables. A model is regarded as the Vector Error Correction (VEC) model by adding a cointegration relationship. The VEC model is:

$$
\begin{aligned}
& \Delta \mathrm{y}_{\mathrm{t}}=\alpha_{10}+\alpha_{11} \text { ect }_{\mathrm{t}-1}+\mathrm{v}_{\mathrm{t}}^{\mathrm{y}} \\
& \Delta \mathrm{x}_{\mathrm{t}}=\alpha_{20}+\alpha_{21} \text { ect }_{\mathrm{t}-1}+\mathrm{v}_{\mathrm{t}}^{\mathrm{x}}
\end{aligned}
$$

Where $\Delta$ as usual denotes the first difference operator, $v_{t}$ is a random error term, and ect $t_{t-1}=y_{t-1}-\beta_{0}-\beta_{1} x_{t-1}$ that is the one-period lagged value of the error from the cointegrating regression. VEC shows that the I(1) variable $y_{t}$ is related to other lagged variables $\left(y_{t-1}\right.$ and $x_{t-1}$ ) and where the $I(1)$ variable $x_{t}$ is also related to the other lagged variables $\left(\mathrm{y}_{\mathrm{t}-1}\right.$ and $\left.\mathrm{x}_{\mathrm{t}-1}\right)$ (Hills et al. 2011). Suppose that three price variables in this study are cointegrated, hence the error-correcting model (ECM) is represented by:

$$
\begin{aligned}
\Delta P_{t}^{S B}=\beta_{10}+ & \beta_{11} \Delta P_{t-1}^{S B}+\beta_{21} \Delta P_{t-1}^{S M} \\
& +\beta_{31} \Delta P_{t-1}^{S O}+\beta_{41} e c t_{t-1} \\
& +v_{t}^{S B} \\
\Delta_{t}^{S M}=\beta_{20}+ & \beta_{21} \Delta P_{t-1}^{S B}+\beta_{22} \Delta P_{t-1}^{S M} \\
& +\beta_{32} \Delta P_{t-1}^{S O}+\beta_{42} e c t_{t-1} \\
& +v_{t}^{S M} \\
P_{t}^{S O}=\beta_{30}+ & \beta_{31} \Delta P_{t-1}^{S B}+\beta_{32} \Delta P_{t-1}^{S M} \\
& +\beta_{33} \Delta P_{t-1}^{S O}+\beta_{43} e c t_{t-1} \\
& +v_{t}^{S O}
\end{aligned}
$$

Note: $\mathrm{P}_{\mathrm{t}}^{\mathrm{SB}}$ (Soybean Price (USD/tonne)) $\mathrm{P}_{\mathrm{t}}^{\mathrm{SM}}$ (Soybean Meal Price (USD/tonne)); $\mathrm{P}_{\mathrm{t}}^{\text {so }}$ (Soybean Oil Price (USD/tonne)); $\beta_{1,2,3}$ (The coefficient of dynamic short-run); $\beta_{4}$ (The coefficient of error correction model); $v_{t}$ (Residual).

\section{VECM Diagnostic Test}

After an estimate of every model, several evaluations will be performed to validate the suitability of the model. The following ones will be of foremost concern in particular: Lagrange-multiplier (LM) test for autocorrelation in the residuals, Jarque-Bera test for normally distributed residuals. In additionBesides, the eigenvalues stability test will be performed and test whether the expected values of the cointegrated equations are stationary, as defined by the Johansen method (Zaytsev, 2010).

\section{IRF and FEVD}

Impulse Response Functions (IRF) indicate the effect of shocks on the parameters adjustment path when Forecast Error Variance Decompositions (FEVD) assessing the contribution to the prediction error variance of each shock type. Both computations are useful in VAR or VECM to analyze how shocks to economic variables reverberate through a system since the individual coefficients in the estimated VAR models are often difficult to interpret.

\section{RESULTS}

In general, price variables display similar upward movement behavior since 1996, while there is a discernible pattern of prices appear to wander up and down over time. They seem to be wandering or fluctuating around a non-zero sample average; it means the series has a constant without a trend.

The time series of the changes show similar behavior that can describe those variables appear wandering around a constant value of zero means. The fluctuations also appear up and downs in the constant range that means those series have constant variance. Thus, the first difference price of all three soybean joint products display characteristics of the stationary condition.

\section{Unit Root Test}

Table 1 represents the unit root test results. There are Augmented Dickey-Fuller (ADF) and Phillips-Perron tests to confirm stationarity for each price. The test results show that the ADF test fails to reject the null hypothesis of a unit root for each price in levels.

Meanwhile, the first differences of each price generate stationarity as the ADF test rejects the null hypothesis. The Phillips-Perron test provides that the results fail to reject the null hypothesis using level price and reject the null hypothesis of stationarity for each price in the first difference. The results signify soybean and its joint products significantly integrated of order one I(1), which is non-stationary. With the proof that the price series is non-stationary, the test for cointegration between soybean joint product prices pairs using Johansen Cointegration Test proceeded. 
Table 1. Unit root test

\begin{tabular}{|c|c|c|c|c|}
\hline \multirow{2}{*}{ Variable } & \multicolumn{2}{|c|}{$\mathrm{ADF}$} & \multicolumn{2}{|c|}{ Phillips-Perron } \\
\hline & Level & $1^{\text {st }}$ Difference & Level & $1^{\text {st }}$ Difference \\
\hline $\operatorname{Ln} \mathrm{P}_{\mathrm{t}}^{\mathrm{SB}}$ & -1.379 & $-13.959 * * *$ & -1.587 & $-13.944 * * *$ \\
\hline $\operatorname{Ln} \mathrm{P}_{\mathrm{t}}^{\mathrm{SM}}$ & -1.239 & $-11.546^{* * *}$ & -1.596 & $-11.422 * * *$ \\
\hline Ln $\mathrm{P}_{t}^{\mathrm{SO}}$ & -1.178 & $-11.642 * * *$ & -1.544 & $-11.691 * * *$ \\
\hline
\end{tabular}

*** Significant at 1\% level of probability; Source: Author's Calculation, FAO (2019)

\section{Lag Length Selection}

Several test statistics like Akaike Information AIC, BIC, and HQ Criterion were used to select the order of the VAR model in Johansen's cointegration technique and VECM. To choose each model's optimal lag length, the log-likelihood function model was maximized. That was done by selecting the model with the lowest criterion and cross-checking every single result to ensures accuracy.

All three criteria held two lags for the best choice as a compromise between the goodness of fit and parsimonious of the model. In Table 2, the VAR lag order selection results provided several options for length, which all the criteria suggested an optimal lag of two. It would be appropriate and fit with the model. The small number of lags retained a high degree of freedom and avoided increasing the likelihood of multicollinearity.

\section{Johansen Cointegration Test}

The Johansen cointegration test was used to detect if non-stationary prices of soybean joint products move together in the long-run. Since the price pattern indicated that the series had constant without trend, restricted constant applied in cointegration and vector error correction model. By adding the restriction, it was assumed that there were no linear time trends in the levels of the data. This specification enabled the cointegrating equations to be stationary around a constant mean, but it did not allow for any other trends or constants.

The results of the cointegration analysis were summarized in Table 3. To acquire a complete perspective, the Johansen test was used to examine each possible pair of soybean joint products, both in single pair and simultaneous analysis. The Johansen test failed to reject the null hypothesis of no cointegration between soybean and soybean oil prices. Correspondingly, the result denoted the pair price of soybean and soybean oil was not cointegrated. However, there was evidence of a cointegrating relationship in Soybean and soybean meal price at a 10\% significance level, but the simultaneously model seems to give superior interpretation since it had a higher significance level.

Furthermore, when the Johansen test included all three prices together as the dependent variable, there was at least one cointegration vector linking the markets. The result rejected the null hypothesis of no cointegration but failed to reject the null hypothesis of one cointegrating vector. Thus, this result reveals the existence of a long-run relationship between soybean, soybean meal, and soybean oil prices simultaneously. Hence, it can be concluded that since all prices were cointegrated, VECM was used to observe the extent of their elasticity relationship.

\section{Vector Error Correction Model}

The Johansen test output gave a superficial overview of the error correction mechanism. Cointegration test results demonstrated that there was one equilibrium relationship between the three prices in the long run. That implied the series was related and could be combined linearly.

From the results of the cointegration test, it was also possible to check whether the signs of the coefficients are in line with the prediction of economic theory. According to Gardner's joint-products equation (1987), the price of soybeans can be represented as a weighted average of returns from soybean meal and soybean oil less the processing (crushing) margin.

To resembles this theoretical expectation, the equation must be normalized. The coefficient for soybean price is the system's endogenous variable and placed to the left-hand side while soybean meal and soybean oil are exogenous. Thus, the underlying long-run relationship is: 
Table 2. VAR lag order selection criteria

\begin{tabular}{cccccc}
\hline Lag & loglik & $\mathrm{p}(\mathrm{LR})$ & $\mathrm{AIC}$ & $\mathrm{BIC}$ & $\mathrm{HQC}$ \\
\hline 1 & 1388.99572 & & -9.942207 & -9.785210 & -9.879214 \\
2 & 1424.91320 & 0.00000 & $-10.136557^{*}$ & $-9.861812^{*}$ & $-10.026319^{*}$ \\
3 & 1430.68515 & 0.24026 & -10.113250 & -9.720757 & -9.955767 \\
4 & 1439.10347 & 0.05134 & -10.109050 & -9.598810 & -9.904322 \\
\hline
\end{tabular}

* indicates lag order selected by the criterion; Source: Author's Calculation, FAO (2019)

Table 3. Johansen cointegration test

\begin{tabular}{|c|c|c|c|c|c|c|}
\hline $\begin{array}{c}\text { Dependent } \\
\text { Variable }\end{array}$ & Rank & Trace Test & p-value & L-max Test & p-value & Result \\
\hline $\operatorname{Ln} P_{t}^{S B}$ & 0 & 18.652 & 0.0814 & 15.735 & 0.0511 & $\mathrm{r}=1^{*}$ \\
\hline $\operatorname{Ln} \mathrm{P}_{t}^{\mathrm{SM}}$ & 1 & 2.9168 & 0.6027 & 2.9168 & 0.6031 & \\
\hline $\operatorname{Ln} P_{t}^{S B}$ & 0 & 16.469 & 0.1558 & 13.849 & 0.1028 & $\mathrm{r}=0$ \\
\hline Ln $\mathrm{P}_{\mathrm{t}}^{\mathrm{SO}}$ & 1 & 2.6205 & 0.6587 & 2.6205 & 0.6575 & \\
\hline $\operatorname{Ln} \mathrm{P}_{t}^{\mathrm{SM}}$ & 0 & 12.445 & 0.4183 & 9.9506 & 0.3504 & $\mathrm{r}=0$ \\
\hline $\operatorname{Ln~P}_{t}^{\text {so }}$ & 1 & 2.4944 & 0.6822 & 2.4944 & 0.6810 & \\
\hline $\operatorname{Ln} P_{t}^{S B}$ & 0 & 56.524 & 0.0000 & 43.940 & 0.0000 & $\mathrm{r}=1 * * *$ \\
\hline $\operatorname{Ln} \mathrm{P}_{\mathrm{t}}^{\mathrm{SM}}$ & 1 & 12.584 & 0.4064 & 10.090 & 0.3376 & \\
\hline $\operatorname{Ln} \mathrm{P}_{\mathrm{t}}^{\mathrm{so}}$ & 2 & 2.4946 & 0.6821 & 2.4946 & 0.6810 & \\
\hline
\end{tabular}

*** means significance difference $\mathrm{P}<0.01,{ }^{* *} 0.05, * 0.10$; Source: Author's Calculation, FAO (2019)

Note: with restricted constant and two lags

$$
\begin{gathered}
\ln P_{t-1}^{S B}=0.492 \ln P_{t-1}^{S M}+0.422 \ln P_{t-1}^{S O} \\
+0.274+e c t_{t-1}
\end{gathered}
$$

As expected, the estimation of soybean price functions has produced positive signs on its joint products, soybean meal, and soybean oil price. Since oil and meal are both produced from the bean, the price of a bean is a weighted average of the oil and the meal prices, with weights roughly equal to the shares of oil and meal, respectively, in each quantity of beans.

Based on the cointegration equation, assumed other things equal, each percentage-point increase in soybean meal would cause an increase of 0.492 percentage points in soybean price. Additionally, each percentage-point increase in soybean oil price has an effect of increasing soybean price about 0.442 percentage points.

However, this positive coefficient probably gives another perspective about the relation of soybean and its joint products associated with their market. Recall that this research did analyze Rotterdam soybean price, Hamburg soybean meal price, and Dutch soybean oil price. Now, associated with the cointegration equation, positive constant reveals that soybean Rotterdam price exceeds the weighted average of the Dutch oil and the Hamburg meal prices. This result indicates soybean Rotterdam not processed by European domestic processors to obtain Dutch Oil and Hamburg meals. Processing soybean Rotterdam will make losses for the processor. Hence, perhaps the soybean Rotterdam price has no joint product correlation towards Hamburg meal and Dutch oil price.

This result in line with the previous study. Pritchett et al. (2006) revealed that there is a weak correlation between crush margin towards soybean, meal, and oil future price. Their analysis shows that estimated crush margins do not follow the same monthly average price pattern as soybean and its joint products. This reflects the fact that considering the crush margin as a linear dependence of soybean price is not too clear, particularly when the price associated with complex trade action. This evidence then reinforced by another literature. Piggott and Wohlgenant (2002) indicated that the elasticities relationship of joint products and the raw product are not straightforward if they are traded internationally, and there are policy interventions.

Both literature results strengthen the assumption that there is no crushing process from Rotterdam soybean to produce neither Hamburg meal nor Dutch oil. This is plausible because, mostly, the EU satisfies their domestic soybean demand by importing them. The EU is the biggest soybean meal importer to meet the demand, mostly for their livestock feed. To produce 
vegetable oil, they are centered on processing rapeseed and sunflower seed. In other words, there are not many domestic processors in the EU doing the soybean crushing process (USSEC, 2008).

In short, considering the crush margin as the constant of the joint products in the international price equation perhaps generates misinterpretation, particularly when regressing the model with the international price. However, it possibly fits the joint products model at the domestic or farm price level, where there is minor price intervention occurs. However, even though there is no joint product correlation between all three prices, they remain to have a long-run relationship.

The estimation results for the short-run model included the ect $t_{t-1}$ from the long-run equation presented in Table 4. The corresponding adjustment coefficients for each equation were -0.3134 for the soybean, 0.0439 for soybean meal, and -0.0129 for soybean oil. However, the adjustment coefficient in the soybean meal and soybean oil price equation were not statistically significant. The adjustment towards the long-run equilibrium took place only through changes in soybean prices. Soybean price is the only price that reacts to the correct equilibrium. This plausible because the markets for oil and meal are plentiful. The increases in meat consumption globally are expected to lead to increased livestock production, at the same time boosting the demand for soybean meal for feed use. Moreover, the broad demand for food, industrial applications, and biofuel makes soybean oil do not follow both meal and soybean prices.

Additionally, there are many substitutes that soybean meal and soybean oil must compete with. There are several substitutes for a protein source, namely corn, cottonseed, and rapeseed. Meanwhile, soybean oil must compete with palm and rapeseed oil, the closest substitutes to produce edible oil and biodiesel.
Therefore, the prices of both oil and meal are perhaps more exogenous, and the price of soybeans is always adjusting as the weighted average of the prices of meal and oil to changes in the prices of these two products.

The significant negative coefficient on ect $t_{t-1}$ indicated that soybean price responded to a temporary disequilibrium between three prices. The negative error correction coefficient in the first equation of -0.3134 indicated that the soybean price got back to equilibrium at $31 \%$ each month when there was a shock. Moreover, when the average bean price was too high, it gradually fell back to correct the equilibrium.

This is not so fast as expected. One possible reason for this relatively slow error correction could be because there is no crushing process between soybean joint products. The crushing process at a domestic level probably transmits the price transmission rapidly. However, the exogenous variable, such as demand for other oilseeds, dollar depreciation, restriction policies, GMO issues, and crush spread speculation, perhaps more significantly affect the adjustment price but take a longer time. Hence, the adjustment process to restore the equilibrium cannot be fast.

\section{VECM Diagnostic Test}

After estimation has been carried out, and the results have been obtained, several tests would be carried out to determine how adequate the model. First, the Lagrange-multiplier (LM) test was performed to detect the existence of autocorrelation in the residuals up to the lag order of 12 . At the $5 \%$ and $10 \%$ significance level, the null hypothesis could not be rejected either with one or two lags. This revealed that the residuals of the model did not seem to be affected by a significant autocorrelation. Therefore, no evidence of model misspecification was identified.

Table 4. VECM estimation results and test

\begin{tabular}{|c|c|c|c|}
\hline \multirow{2}{*}{ Independent Variable } & \multicolumn{3}{|c|}{ Dependent Variable } \\
\hline & $\Delta \ln \mathrm{P}_{\mathrm{t}-1} \mathrm{SB}$ & $\Delta \ln \mathrm{P}_{\mathrm{t}-1}^{\mathrm{SM}}$ & $\Delta \ln \mathrm{P}_{\mathrm{t}-1}^{\mathrm{SO}}$ \\
\hline$\Delta \ln \mathrm{P}_{\mathrm{t}-1} \mathrm{SB}$ & 0.0636 & 0.0199 & 0.0714 \\
\hline$\Delta \ln \mathrm{P}_{\mathrm{t}-1} \mathrm{SM}$ & $0.1368 *$ & $0.2906^{* * *}$ & -0.0185 \\
\hline$\Delta \ln \mathrm{P}_{\mathrm{t}-1}$ so & $0.1845^{* *}$ & $0.1344^{*}$ & $0.3058 * * *$ \\
\hline $\mathrm{ect}_{\mathrm{t}-1}$ & $-0.3134 * * *$ & 0.0439 & -0.0129 \\
\hline
\end{tabular}


Besides, a test was performed to assess whether the model satisfies eigenvalue stability and cointegration conditions. Stability test VECM was said to have high stability when the characteristic polynomial of autoregressive has modulus $\leq 1$. The result showed that the modulus of the characteristics of roots at all lag is $\leq 1$. Thus, it can be concluded that the model is appropriate to be used since it has high stability. Moreover, the ADF test for the cointegrating term rejects the null hypothesis of a unit root in level at a $1 \%$ significance level. This showed that the cointegrating term obtained from the estimated VECM was stationary. The zero average lines represented a stable and long-term equilibrium relationship among variables, as predicted by theory.

Nevertheless, the situation was worse regarding the vector tests for residuals normality via the Jarque-Bera test. Judging by the low p-values, the null hypothesis of normality in every equation was rejected at conventional significance levels of $1 \%$. This indicated that every single equation contained non-normality residual and probably lead to model misspecification.

However, violating the normality assumption might not be a serious issue given the premise of asymptotic normality insufficiency large sample size and with the condition that other assumptions hold (Wooldridge, 2002). Consequently, since all the previous test indicated the reasonability of the model estimation, further steps of the analysis can undertake.

\section{Impulse Response and Variance Decomposition}

Impulse response functions depict the effects of shocks on the adjustment path of the bean prices towards meal and oil prices; meanwhile, forecast error variance decompositions will measure the contribution of each type of shock to the forecast error variance. Both computations are assessing how shocks of meal and oil prices reverberate by soybean prices through a system. The horizontal axis represents the period in 15 months, while the vertical axis shows the response value in percent.

The IRF reveals that a one-time positive shock from meal and oil price leads to a permanent increase in soybean price. Firstly, the result explains that a $1 \%$ increase in meal price will induce a continuous rise in the bean price of $0.03 \%$. Secondly, another IRF interpretation indicates a $1 \%$ shock to oil price will permanently increase by about $0.027 \%$ in bean price. Both the positive response from soybean price gradually incline until the sixth period when it hits steady-state value and remains in the positive region.

Thirdly, it depicts the response of soybean towards its price shock. Interestingly, $1 \%$ of shocks in soybean price will cause a temporary increase to its rice from $0.052 \%$ to $0.058 \%$. After hits a peak in the first period, there is a quick decline in the next period to $0.057 \%$. Further, the response value continues to decrease slowly until the tenth period and hits a steady-state value of $0.048 \%$. This movement response indicates that if there is a shock occurs in soybean price, it will correct its price to obtain equilibrium in the long-run.

When impulse response function is adopted to represents the shock effect of internal soybean jointproducts price, variance decomposition can be used to evaluate the influence of each price change on other prices that show relative impacts. According to bean price predicted variance, the contribution of bean price change begins to decline from the first period quickly, reaches $80 \%$ in the fifth period, and then stably drops to $67 \%$ in the fifteenth period.

The oil price contribution rate gently rises to $16 \%$ in the tent period and then slightly increases to $18 \%$ until the last period. At the same time, the contribution rate of meal prices slowly rises to $12 \%$ in the tenth period and then basically maintains stability. In other words, soybean oil has more contribution to soybean price change compared to soybean meal. This possibly reflects the facts already mentioned that soybean oil more highly-priced than soybean meal. It can be seen from the price movement provided by FAO, soybean oil prices always higher than meal and bean prices for the last decades. This occurred due to the oil extracted from soybean is the main product for various uses and the demand for it is also huge (USSEC 2008). Hence, soybean price tends to follow soybean oil price compare to its meal and own prices.

\section{Managerial Implications}

This research identified whether there was a significant long-term relationship among these three variables through cointegration tests and VECM. Impulse response and variance decomposition were also performed to interpret the results. 
Interestingly, based on the results of this study, changes in soybean prices did not significantly affect the price of its oil and meal. However, the price change in soybean oil and meal only significantly affected by its price in the last period. The price change for oil and meal perhaps more influenced by other factors and other markets.

Regarding the soybean market, the world's need for soybean and its joint products creates a competitive market worldwide. For example, soybean products compete with wheat as human food, soybean meal competes with corn as feed, and soybean oil competes with palm oil like vegetable oil. Besides, the contribution of soybean and soybean meal as a source of protein is also dominant globally.

However, the contribution of soybean oil as a source of vegetable oil was still inferior to palm oil, where palm oil production was still dominated by Indonesia (OEC, 2020). This competition put palm oil and soybean oil in the same market and perhaps affect one and another.

Policy stakeholders in Indonesia should consider this soybean joint products price transmission. As the largest producer of palm oil (USDA, 2019), the stakeholder should maintain the price change in palm oil to compete with the soybean oil price. Since soybean oil price is more independent from another joint product effect, it perhaps has a stable price in the market and possibly creates a though competition for Indonesia's palm oil market.

Simultaneously, Indonesia also the largest importer of soybean meal (OEC, 2020). Importing soybean meal rather than import soybean and process it domestically is the recommended decision. This research implies that soybean meal price is more independent than soybean meal. This means that the price of soybean meal has greater stability than the soybean. It probably creates a good environment for the food and feed industry.

\section{CONCLUSIONS AND RECOMMENDATIONS}

\section{Conclusions}

There was one cointegration among soybean and its joint products. Since oil and meal are both produced from the bean, the price of a bean is a weighted average of the oil and the meal prices. Assumed other things equal, each percentage-point increases in meal price will cause a rise of 0.492 percentage points in bean price. Additionally, each percentage-point increases in oil price have an effect of increasing bean price about 0.442 percentage points.

Although, the positive constant of the cointegration equation was violated the expected theory. This constant reveals that soybean Rotterdam price exceeds the weighted average of the Dutch oil and the Hamburg meal prices. This indicates soybean Rotterdam price has no joint product correlation towards Hamburg meal and Dutch oil price. This is in line with the previous study that presents there is a weak correlation between the crushing margin and soybean joint products, particularly in the global market.

VECM empirical results indicated that in the longrun, soybean price is the only one that reacts to correct equilibrium. This is reasonable since oil and meal have huge markets. Moreover, several possible substitutes can easily switch the demand of these joint products. If there is a shock, the soybean price gets back to equilibrium at $31 \%$ each month. However, this adjustment speed is not so quickly as expected since probably there is no actual relation between all variables; perhaps other exogenous variables have more significant influence to make soybean correcting the equilibrium slower.

An interesting conclusion was reached when the pattern of the impulse response functions was compared. Soybean prices respond to meal and oil price shocks with a steady increase of up to the sixth month. However, when there is a shock in soybean price, its price will decline slowly to correct the deviation, until it hits constant value in the fifteenth month. According to FEVD results, soybean oil generates more contribution to soybean price change compared to soybean meal. This perhaps occurs since soybean oil has the highest price among these products. Thus, soybean price change tends to follow its oil price rather than its meal and its prices.

\section{Recommendations}

However, some limitations should be noted. This research regressed the variable of the international price that possibly violated the soybean joint products theory. A further research step may be to analyze the price at the domestic or farm level to fulfill the joint products 
model. Furthermore, it is essential to consider involving exogenous variables that perhaps significantly affect the price transmission of soybean and its joint products. Lastly, this study can help traders and policymakers understand that there is a price transmission occurs in soybeans and its joint products' prices, globally. For instance, the changes in soybean oil prices of the biodiesel market perhaps affect the meal and bean prices for animal feed and human food markets. This dynamic of the soybean market must be considered to maintain the stability of prices and supplies of each soybean products.

\section{REFERENCES}

Arnold BC, Balakrishnan N, Alegria JMS, Minguez R. 2008. Advances in Mathematical and Statistical Modeling. New York: Springer Science, and Business Media.

Brooks J, Melyukhina O. 2003. Estimating the passthrough of agricultural policy reforms: an application to Russian crop markets, with possible extensions, mimeo, OECD, Paris.

Brooks C. 2008. Introductory Econometrics for Finance. Cambridge: Cambridge University Press.

Enders W. 2015. Applied Econometrics Time Series. New Jersey: John Wiley and Sons.

Engle RF, Granger CWJ. 1987. Cointegration and error correction: representation, estimation, and testing. Econometrica 55(2):251-276.

FAO. 2019. GIEWS FPMA Tool. Food and Agriculture Organization of the United Nations, Rome. http:// www.fao.org/giews/food-prices/tool/public/\#/ dataset/international. [29 Oct 2019].

Freitas SM, Margarido MA, Barbosa MZ, Franca TJF. 2001. Análise da dinâmica de transmissão de preços no mercado internacional de farelo de soja. Agricultura em São Paulo 48(1):1-20.

Gardner B. 1987. The Economics of Agricultural Policy. Washington D.C.: Macmillan Publishing Company.

Hamilton JD. 1994. Time Series Analysis. New Jersey: Princeton University Press.

Hill RC, Griffiths WE, Lim GC. 2011. Principles of Econometrics. New Jersey: John Wiley and Sons.
Margarido MA, Turolla FA, Bueno CRF. 2007. The world market for soybeans: price transmission into Brazil and effects from the timing of crop and trade. Nova Economia 17(2):241-270.

OEC. 2020. Soybean Meal. The Observatory of Economic Complexity, Massachusetts. https:// oec.world/en/profile/hs92/2304/. [29 Jan 2020].

.2020. Soybean Oil. The Observatory of Economic Complexity, Massachusetts. https://oec.world/ en/profile/hs92/1507/. [29 Jan 2020].

. 2020. Soybean. The Observatory of Economic Complexity, Massachusetts. https://oec.world/ en/profile/hs92/1201/. [29 Jan 2020].

Piggott NE, Wohlgenant MK. 2002. Price elasticities, joint products, and international trade. The Australian Journal of Agricultural and Resource Economics 46(4):487-500.

Pritchett T, Smith A, Johnson T. 2016. Implications for Soybean and Livestock Producers From Relationships in The Soybean, Soybean Oil and Soybean Meal Markets. Department of Agricultural and Resource Economics, University of Tennessee, Institute of Agriculture, Tennessee.

Soon BM, Whistance J. 2019. Seasonal soybean price transmission between the U.S. and Brazil using the seasonal regime-dependent Vector Error Correction Model. Sustainability 11(19): 1-9.

USDA. 2019. Oilseed: World and Markets Trade. The United States Department of Agriculture, Washington. http://apps.fas.usda.gov/psdonline/ psdDataPublications.aspx [29 Oct2019].

USSEC. 2008. How the Global Oilseed and Grain Trade Works. The United States Soybean Export Council, Missouri. https://ussec.org/wp-content/ uploads/2015/10/How-the-Global-Oilseed-andGrain-Trade-Works.pdf. [29 Jan 2020].

Wohlgenant MK. 1999. Product heterogeneity and the relationship between retail and farm prices. European Review of Agricultural Economics 26(2):219-227.

Wooldridge JM. 2002. Introductory Econometrics: A Modern Approach. Mason: South-Western College Publishing.

Zaytsev O. 2010. The impact of oil price changes on the macroeconomic performance of Ukraine [Thesis]. Ukraine: Kyiv School of Economics. 